\title{
Current Situation about the Awareness of Managers and Lecturers of Vietnamese Public Universities on Implementing the Accountability
}

\author{
Dinh Xuan Khoa ${ }^{1}$, Pham Minh Hung ${ }^{2}$, Pham Le Cuong ${ }^{3}$, Nguyen Thi Thu Hang,** \\ Vinh University, Viet Nam \\ *Corresponding author: ntthuhang81@gmail.com
}

Received July 21, 2019; Revised September 06, 2019; Accepted September 19, 2019

\begin{abstract}
The article mentions the current situation about the awareness of managers and lecturers of Vietnamese public universities on implementing the accountability. Survey results show that the awareness of managers and lecturers of Vietnamese universities on implementing the accountability still has certain limitations and shortcomings. From that, the article has proposed a number of measures to raise the awareness of Vietnamese university managers and lecturers on the implementation of accountability: Organizing research, thoroughly grasping in managers and lecturers about the need to implement the accountability; Diversifying the forms of dissemination and propaganda for managers and lecturers to be fully aware of the implementation of the accountability; Overcoming the incorrect and incomplete perceptions of implementing the accountability in universities.
\end{abstract}

Keywords: accountability, public university, awareness, current situation

Cite This Article: Dinh Xuan Khoa, Pham Minh Hung, Pham Le Cuong, and Nguyen Thi Thu Hang, "Current Situation about the Awareness of Managers and Lecturers of Vietnamese Public Universities on Implementing the Accountability.” American Journal of Educational Research, vol. 7, no. 9 (2019): 632-639. doi: 10.12691/education-7-9-5.

\section{Introduction}

University autonomy is a mainstream of world higher education in general and higher education in Vietnam in particular. Autonomy will facilitate and motivate universities to develop in their own way. However, university autonomy must be associated with accountability. The higher the degree of university autonomy, the greater the accountability of the university. Many people have argued that university autonomy is like a "gas pedal", while accountability is like a "brake pedal" in a car [1]. University autonomy helps universities "speed up" on the long road; while accountability helps universities not deviate from orbit which is limited by the provisions of the law [2]. In the world, university autonomy and accountability are not new issues but are still the core content in discussions about higher education development [3]. When the higher education model changes from state control to state oversight, the autonomy and accountability of universities are further enhanced [4]. Since then, a number of foreign authors have introduced different university autonomy models, but the University Council model is still a particularly emphasized model [5]. Not the principal but the university council itself is the key player in the implementation of university autonomy and accountability [6]. Therefore, the research of university autonomy and accountability must be associated with promoting the role of the University Council in universities [7]. For Vietnamese public universities, university autonomy and accountability are still relatively new issues [8]. Therefore, studying the awareness of managers and lecturers of public universities in Vietnam on accountability, thereby proposing awareness raising measures for managers and lecturers of public universities in Vietnam on accountability is a matter of scientific significance and urgency.

Research Results about the Current Situation of the Awareness of the Managers and Lecturers of Vietnamese Public Universities on the Accountability.

\subsection{The Survey Process}

\subsubsection{Objectives of Surveying the Current Situation}

The objective of the survey is to assess properly and objectively the reality of awareness of managers and lecturers at Vietnamese public universities on implementing the accountability.

\subsubsection{Contents of Surveying the Current Situation}

The content of the survey focuses on the following key issues: 1) The reality of awareness about the concept of accountability; 2) The reality of awareness about the 
concept of university accountability; 3) The reality of awareness about meaning, importance for the implementation of university accountability; 4) The reality of awareness about the content of university accountability implementation; 5) The reality of awareness about the way to implement the accountability of the university.

\subsubsection{Sample and Survey Object}

\section{- For universities}

The universities selected for the survey must meet the following criteria: 1) They must be public universities; 2) They belong to different managing agencies (Ministry of Education and Training; Other ministries; People's Committees of provinces / cities); 3) There are different levels of autonomy (full autonomy, partial autonomy and dependence); 4) They are in different regions; 5) The number of universities is sufficient to facilitate the survey (5-6 universities).

Based on the identified criteria, the research team selected the following five public universities to survey: Can Tho University; Hanoi University of Industry, Saigon University; Ho Chi Minh City University of Technical Education and Vinh University.

\section{- For managers and lecturers}

Managers are the survey object of the research team including: Board of Directors; Head, Deputy Head of the Faculty/Training institute; Head, Deputy Head of Department; Director / Deputy Director of the center; Head of the subject. The survey investigated $100 \%$ of managers of 5 selected universities.

As for lecturers, due to the large number, the research team only randomly surveyed $10 \%$ (the sample distance is 10) the number of lecturers of the 5 selected universities. The survey sample is shown in Table 1.

Table 1. Information about the survey object

\begin{tabular}{|l|c|c|c|}
\hline \multirow{2}{*}{ Universities } & \multicolumn{2}{|c|}{ Objects of the survey } & \multirow{2}{*}{ Total } \\
\cline { 2 - 3 } & Managers & Lecturers & \\
\hline Can Tho University & 136 & 100 & 236 \\
\hline Hanoi University of Industry & 102 & 186 & 288 \\
\hline Saigon University & 53 & 21 & 74 \\
\hline $\begin{array}{l}\text { Ho Chi Minh University of Technical } \\
\text { Education }\end{array}$ & 137 & 72 & 209 \\
\hline Vinh University & 131 & 69 & 200 \\
\hline Total & $\mathbf{5 5 9}$ & $\mathbf{4 4 8}$ & $\mathbf{1 0 0 7}$ \\
\hline
\end{tabular}

\subsubsection{Survey Method}

- Preparing the survey form to solicit opinions of managers and lecturers of public universities

The implementation of the survey form is carried out in the following steps: 1) Discuss with the survey objects and experts to formulate the survey form; 2) Prepare the $1^{\text {st }}$ survey form; 3) Get advice of experts and test on small samples; 3) Correct the survey form and compile the official one ( $2^{\text {nd }}$ edition); Select the survey sample; Organize to collect opinions through the survey form and discuss with survey objects about issues that need to be studied but not mentioned in the survey form; Process information from the survey form by the mathematical statistical method.

\section{- Exchanging, interviewing by topics}

The content of the exchange topics focused on the following issues: Accountability activities performed at public universities; Advantages and disadvantages in accountability activities at public universities; Impact of accountability activities on public universities, etc.

- Researching the products of activities of public universities managers and lecturers

The products of activities of managers and lecturers include: reports, plans, regulations, etc. related to the content of surveying the reality of the research team.

\subsubsection{The Method of Data Processing and Evaluation Scale}

- The method of data processing

The method of data processing is done as follows: Data collected from the survey form are processed according to SPSS software.

\section{- Evaluation scale}

Data collected from the survey form were evaluated in conformity; At the same time, it is divided into 5 levels, from low to high (corresponding to scores from 1 to 5): Completely inappropriate; Less appropriate; Relatively appropriate; Quite appropriate and Perfectly appropriate.

\section{Each level has a certain average value.}

Table 2. Evaluation scale of survey results on the awareness of accountability

\begin{tabular}{|c|c|l|}
\hline Order & The average value & Level of appropriateness \\
\hline 1 & $1.00-1.80$ & Completely inappropriate \\
\hline 2 & $1.81-2.60$ & Less appropriate \\
\hline 3 & $2.61-3.40$ & Relatively appropriate \\
\hline 4 & $3.41-4.20$ & Quite appropriate \\
\hline 5 & $4.21-5.00$ & Perfectly appropriate \\
\hline
\end{tabular}

\subsubsection{Survey Time}

All commnets and survey forms were sent to the survey objects from October 2017 and revoked the comments and survey forms in May 2018.

\subsection{Results of Surveying the Current Situation}

\subsubsection{The Reality about Awareness of the Survey Objects on the Concept of Accountability}

Results from Table 3 show:

Firstly, the average score of managers' awareness on the concept of accountability lies in the range of 3.06 - 3.57. With this average score, the awareness of managers on accountability concept fluctuates between Relatively and Quite appropriate level. As for lecturers, the average score of awareness on accountability concepts ranges from 2.38 to 3.44 . With this average score, the lecturers' awareness has a larger fluctuation range, from Less appropriate level to Quite appropriate one.

Secondly, in the understanding ways of the accountability concept given, for managers, the understanding way that Accountability is an acknowledgment of responsibility for every action, every product, every decision or policy given in leadership, management and performance of the work has the highest average score (ranked $1^{\text {st }}$ ); Next is the understanding way that Accountability is self-responsibility for the work they do (ranked $2^{\text {nd }}$ ); Accountability is the responsibility for explaining the 
performance of the tasks, public duties or issues related to their management responsibilities when required (ranked $3^{\text {rd }}$ ). As for lecturers, these positions are: Accountability is self-responsibility for the work they do (ranked $1^{\text {st }}$ ); Accountability is an acknowledgment of responsibility for every action, every product, every decision or policy given in leadership, management and performance of the work (ranked $2^{\text {nd }}$ ); Accountability is the responsibility of state officials and public servants to implement their assigned jobs effectively and suffer consequences when they have not fulfilled their responsibilities (ranked $3^{\text {rd }}$ ).

If for managers, the understanding way that Accountability is to present, explain the part of work assigned or considered as assigned which must be completed, if the result is not good, they must bear a part of responsibility is at the lowest rank (ranked $5^{\text {th }}$ ) while for lecturers, the understanding way at the lowest level is that Accountability is an acknowledgment of responsibility for every action, every product, every decision or policy given in leadership, management and performance of the work.

The difference about the awareness of the accountability concept between managers and lecturers is not very meaningful, as these are all understanding ways from different perspectives of this concept. It is worth noting here that the way of understanding the concept of accountability depends on the position, role of the survey object and their perspective of the issue.

\subsubsection{The Reality about Awareness of the Survey Objects on the Concept of University Accountability}

From the results of Table 4, the following comments can be drawn:

Firstly, compared to the awareness on the concept of accountability, managers' perception on the concept of university accountability is lower. Only two understandings of university accountability are considered Quite appropriate by managers (level 4); The remaining understandings are considered Relatively appropriate (level 3). For the lecturers, the situation is similar. All 5 ways to understand the concept of accountability of universities are considered to be Relatively appropriate by lecturers.

Secondly, if based on the average score, it can be seen that the awareness of managers is higher than that of lecturers in all 5 understandings about the concept of university accountability: 3.69> 3,23; 3.35> 3.22; 3.49> 3.30, etc. At the same time, with standard deviations at all managers' understandings of the accountability concept of the university is always lower than that of lecturers, so this difference is meaningful.

Thirdly, of all understandings of university accountability, for managers, the understanding that The accountability of the university is the obligation to fully inform all university activities with the stakeholders and to commit to implementing these activities in a quality way, otherwise they will be accountable to the law and stakeholders deemed to be the most appropriate (ranked $1^{\text {st }}$ ); Next is the understanding that Accountability of the university is the obligation of the university to publicize the quality of training, scientific research, quality assurance conditions according to the commitments of the university itself to stakeholders (ranked $2^{\text {nd }}$ ); The university's accountability is the responsibility of reporting to the governing body and to state institutions that have university management functions on the entire university operation (ranked $3^{\text {rd }}$ ). These are considered to be 3 fairly explicit understandings and includes the characteristic sign of the university's accountability concept.

For the lecturers, the 3 highest-ranking understandings are: Accountability of the university is the obligation of the university to publicize the quality of training, scientific research, quality assurance conditions according to the commitments of the university itself to stakeholders (ranked $1^{\text {st }}$ ); The university's accountability is the obligation to fully inform all university activities with the stakeholders and to commit to implementing these activities in a quality way, otherwise they will be accountable to the law and stakeholders (ranked $2^{\text {nd }}$ ); The university's accountability is the responsibility of reporting to the governing body and to state institutions that have university management functions on the entire university operation (ranked $3^{\text {rd }}$ ).

The highest- ranking understandings of accountability concept of lecturers coincide with the highest-ranking understandings of this concept of managers. The only difference is that for the same understanding, managers are at the first rank while lecturers are at the $2^{\text {nd }}$ rank.

Table 3. Results about the awareness of survey objects on the concept of accountability

\begin{tabular}{|c|c|c|c|c|c|c|c|}
\hline \multirow[b]{2}{*}{ Order } & \multirow[b]{2}{*}{ Content } & \multicolumn{3}{|c|}{ Managers (559) } & \multicolumn{3}{|c|}{ Lecturers (448) } \\
\hline & & $\bar{X}$ & $\begin{array}{r}\text { Standard } \\
\text { deviation }\end{array}$ & Level & $\bar{X}$ & $\begin{array}{r}\text { Standard } \\
\text { deviation }\end{array}$ & Level \\
\hline 1 & $\begin{array}{l}\text { Accountability is to present ,explain the part of the work assigned or } \\
\text { considered as assigned which must be completed, if the result is not good, } \\
\text { the implementer must bear a part of the responsibility }\end{array}$ & 3.06 & 1.216 & 3 & 2.38 & 1.401 & 2 \\
\hline 2 & $\begin{array}{l}\text { Accountability is responsibility for explaining the implementation of tasks, } \\
\text { public duties or matters related to their management responsibilities when } \\
\text { required; }\end{array}$ & 3.44 & 1.084 & 4 & 3.02 & 1.454 & 3 \\
\hline 3 & Accountability is self-responsibility for their works; & 3.54 & 1.041 & 4 & 3.44 & 1.208 & 4 \\
\hline 4 & $\begin{array}{l}\text { Accountability is the acknowledgment of responsibility for every action, } \\
\text { every product, every decision or policy given in leadership, management and } \\
\text { performance of the work; }\end{array}$ & 3.57 & 1.063 & 4 & 3.36 & 1.129 & 3 \\
\hline \multirow[t]{2}{*}{5} & $\begin{array}{l}\text { Accountability is the responsibility of state officials and public servants to } \\
\text { implement their assigned jobs effectively and suffer consequences when they } \\
\text { have not fulfilled their responsibilities; }\end{array}$ & 3.19 & 1.104 & 3 & 3.25 & 1.159 & 3 \\
\hline & General average & 3.36 & & & 3.09 & & \\
\hline
\end{tabular}


Table 4. Results about the awareness of the survey objects on the concept of university accountability

\begin{tabular}{|c|c|c|c|c|c|c|c|}
\hline \multirow[b]{2}{*}{ Order } & \multirow[b]{2}{*}{ Content } & \multicolumn{3}{|c|}{ Managers (559) } & \multicolumn{3}{|c|}{ Lecturer (448) } \\
\hline & & $\bar{X}$ & $\begin{array}{l}\text { Standard } \\
\text { deviation }\end{array}$ & Level & $\bar{X}$ & $\begin{array}{l}\text { Standard } \\
\text { deviation }\end{array}$ & Level \\
\hline 1 & $\begin{array}{l}\text { The university's accountability is the obligation to fully inform all university } \\
\text { activities with the parties involved and to commit to carry out these activities } \\
\text { in a quality manner, otherwise it will be responsible before laws and } \\
\text { stakeholders; }\end{array}$ & 3.69 & 1.068 & 4 & 3.23 & 1.212 & 3 \\
\hline 2 & $\begin{array}{l}\text { The university's accountability is the responsibility of reporting to the } \\
\text { governing body and to state institutions that have university management } \\
\text { functions on the entire university operation; }\end{array}$ & 3.35 & 1.131 & 3 & 3.22 & 1.499 & 3 \\
\hline 3 & $\begin{array}{l}\text { The university's accountability is the university's obligation to publicize the } \\
\text { quality of training, scientific research and quality assurance conditions } \\
\text { according to its own commitments to stakeholders; }\end{array}$ & 3.49 & 1.126 & 4 & 3.30 & 1.370 & 3 \\
\hline 4 & $\begin{array}{l}\text { The university's accountability is an acknowledgment of responsibility for } \\
\text { every action, every product, every decision or policy given by the university } \\
\text { in the leadership, management, and performance of the work; }\end{array}$ & 3.14 & 1.035 & 3 & 2.96 & 1.155 & 3 \\
\hline 5 & $\begin{array}{l}\text { The university's } \\
\text { accountability is the transparency of all university activities, in order to help } \\
\text { stakeholders understand the level of implementing the functions and tasks } \\
\text { committed by the university. }\end{array}$ & 3.27 & 1.157 & 3 & 3.19 & 1.188 & 3 \\
\hline & General average & 3.38 & & & 3.18 & & \\
\hline
\end{tabular}

\subsubsection{The Reality of Survey Subjects' Awareness on the Meaning and Importance of Implementing Accountability of Universities}

Results from Table 5 show:

Firstly, most managers and lecturers have a proper awareness of the meaning and importance of implementing the accountability of the university. This is reflected in the fact that the significance and importance of implementing the accountability of the university are considered to be Quite appropriate (level 4) and Relatively appropriate (level 3) by managers and lecturers.

Secondly, management staff's awareness of the significance and importance of implementing university accountability is higher than that of lecturers. In 05 meanings and the importance of implementing university accountability given, all of them are considered Quite appropriate. Meantime, for lecturers, there are only 2 meanings and the importance which are considered Quite suitable; The remaining significances and importance are considered to be Relatively appropriate. If based on the standard deviation, it can also be seen that the perception results of managers are higher than that of lecturers, when at all significances and importance, the standard deviation of managers are always lower than that of lecturers. The above results reflect truly the awareness of managers and lecturers about the meaning and importance of implementing accountability of universities.

\subsubsection{The Reality of Survey Objects' Awareness on the Content of Implementing the University's Accountability}

From the results of Table 6, the following comments can be drawn:

i) Awareness about accountability of training, science and technology

Firstly, the average score of awareness in the contents of implementing the accountability of the university's management staff is basically higher than that of lecturers.

Secondly, the awareness of managers and lecturers is quite consistent, when the hierarchy of contents to implement the accountability of universities is perceived equally by the objects. For example, for two contents: Explanation of the organizational model and operation mode of science and technology organizations; Explanation of the training affiliate program with the foreign training institution at the level corresponding to the level that the institution is training have the first and the second highest average scores for both managers and lecturers. With these two contents, the reason for having high average scores is that these are issues that managers and lecturers do not really understand.

In other contents as well, although there is permutation of adjacent order. For example, for the content: Explanation of enrollment targets and methods, managers are ranked at level 3 while lecturers are ranked at level 4 . But for the content: Explanation of training quality and conditions to ensure training quality, managers are ranked at level 4 while lecturers are ranked at level 3, etc.

Thirdly, for the awareness about the implementation of university accountability of managers and lecturers, the contents with the lowest average score are: Explanation of enrollment targets and methods; Explanation of training quality and conditions to ensure training quality. This result reflects the concerns of managers and lecturers on very important issues for the university.

ii) Awareness about accountability of organizational structure and personnel

Firstly, the similarity of awareness about accountability of organizational structure and personnel of managers and lecturers is quite large. Among the 6 contents of accountability for organizational structure and personnel, there are 5 contents in which awareness of managers and lecturers has the same level (level 4). The reason of this unity is that in recent years, many public universities have not only performed well the organizational structure and personnel but also had many ways to explain this work.

Secondly, in each content of accountability on organizational structure and personnel, awareness of managers is higher than that of lecturers. This is evident when comparing the average score of managers with lecturers.

iii) Awareness about accountability of finance

Firstly, managers and lecturers have a unified awareness of some contents of financial accountability: 
Explanation of tuition fees (all have average score ranked

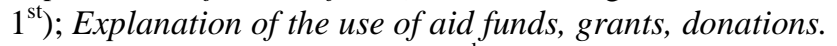
(all with average score ranked $2^{\text {nd }}$ ), etc.

Secondly, only in the content of Explanation of the university's spending activities, between managers and lecturers has certain difference: The average score in this content of managers with a rank of 2 while that of the lecturers is 6 . This difference, to some extent, reflects the incomplete perception of lecturers about spending activities.

Table 5. Results about the awareness of the survey objects on the meaning and importance of implementing accountability of the university

\begin{tabular}{|c|c|c|c|c|c|c|c|}
\hline \multirow[b]{2}{*}{ Order } & \multirow[b]{2}{*}{ Content } & \multicolumn{3}{|c|}{ Managers (559) } & \multicolumn{3}{|c|}{ Lecturers (448) } \\
\hline & & $\bar{X}$ & $\begin{array}{l}\text { Standard } \\
\text { deviation }\end{array}$ & Level & $\bar{X}$ & $\begin{array}{l}\text { Standard } \\
\text { deviation }\end{array}$ & Level \\
\hline 1 & $\begin{array}{l}\text { Ensuring that the university has been } \\
\text { maintaining the basic ethical principles in } \\
\text { implementing its mission; }\end{array}$ & 3.71 & 0.954 & 4 & 3.32 & 1.141 & 3 \\
\hline 2 & $\begin{array}{l}\text { Ensuring that public benefits and resources } \\
\text { are used for the right purpose of the } \\
\text { university; }\end{array}$ & 3.60 & 1.052 & 4 & 3.45 & 1.146 & 4 \\
\hline 3 & $\begin{array}{l}\text { Ensuring that the university does what it } \\
\text { promises to learners and society. }\end{array}$ & 3.61 & 1.021 & 4 & 3.33 & 1.106 & 3 \\
\hline 4 & $\begin{array}{l}\text { Ensuring the publicity and transparency of } \\
\text { all university activities; }\end{array}$ & 3.77 & 0.862 & 4 & 3.52 & 1.143 & 4 \\
\hline \multirow[t]{2}{*}{5} & $\begin{array}{l}\text { Promoting the formation and development } \\
\text { of explanatory culture in the university. }\end{array}$ & 3.64 & 0.873 & 4 & 3.34 & 1.149 & 3 \\
\hline & General average & 3.66 & & & 3.39 & & \\
\hline
\end{tabular}

Table 6. Results about the awareness of the survey objects on the content of implementing the university's accountability

\begin{tabular}{|c|c|c|c|c|c|c|c|}
\hline \multirow[b]{2}{*}{ Order } & \multirow[b]{2}{*}{ Content } & \multicolumn{3}{|c|}{ Managers (559) } & \multicolumn{3}{|c|}{ Lecturers (448) } \\
\hline & & $\bar{X}$ & $\begin{array}{l}\text { Standard } \\
\text { deviation }\end{array}$ & Level & $\bar{X}$ & $\begin{array}{l}\text { Standard } \\
\text { deviation }\end{array}$ & Level \\
\hline 1 & \multicolumn{7}{|l|}{ Explanation of training, science and technology } \\
\hline 1.1 & Explanation of enrollment targets and methods; & 3.28 & 1.181 & 3 & 3.48 & 1.274 & 4 \\
\hline 1.2 & Explanation of training quality and conditions to ensure training quality; & 3.46 & 1.149 & 4 & 3.33 & 1.222 & 3 \\
\hline 1.3 & $\begin{array}{l}\text { Explanation of construction, appraisal, promulgation, implementation } \\
\text { and verification of undergraduate, master and doctoral training programs; }\end{array}$ & 3.62 & 1.193 & 4 & 3.36 & 1.051 & 3 \\
\hline 1.4 & $\begin{array}{l}\text { Explanation of training organization and management for training levels } \\
\text { and forms }\end{array}$ & 3.72 & 1.093 & 4 & 3.42 & 1.138 & 4 \\
\hline 1.5 & $\begin{array}{l}\text { Explanation of organizational model and operation mode of science and } \\
\text { technology organization }\end{array}$ & 3.75 & 1.062 & 4 & 3.58 & 1.170 & 4 \\
\hline 1.6 & $\begin{array}{l}\text { Explanation of the training affiliate program with the foreign training } \\
\text { institution at the level corresponding to the level that the institution is } \\
\text { training }\end{array}$ & 3.74 & 1.086 & 4 & 3.54 & 1.198 & 4 \\
\hline 2 & \multicolumn{7}{|l|}{ Explanation of organizational structure and personnel } \\
\hline 2.1 & Explanation of organizational structure of the university & 3.81 & 0.875 & 4 & 3.39 & 1.312 & 3 \\
\hline 2.2 & $\begin{array}{l}\text { Explanation of the establishment, merger, division, separation and } \\
\text { dissolution of university organizations }\end{array}$ & 3.84 & 0.874 & 4 & 3.41 & 1.118 & 4 \\
\hline 2.3 & $\begin{array}{l}\text { Explanation of recruitment, use, appointment, dismissal, reward, } \\
\text { discipline and management of officials and employees }\end{array}$ & 4.02 & 0.902 & 4 & 3.61 & 1.275 & 4 \\
\hline 2.4 & $\begin{array}{l}\text { Explanation of regimes and policies on attracting, using, training, } \\
\text { fostering and remunerating for highly qualified civil servants, scientists, } \\
\text { managers and laborers; }\end{array}$ & 3.92 & 0.898 & 4 & 3.56 & 1.271 & 4 \\
\hline 2.5 & $\begin{array}{l}\text { Explanation of the organization of the examination or promotion of } \\
\text { professional titles according to current regulations }\end{array}$ & 3.86 & 0.876 & 4 & 3.54 & 1.292 & 4 \\
\hline 2.6 & $\begin{array}{l}\text { Explanation of the construction and approval of the project of job } \\
\text { placement, number of people working, labor structure according to } \\
\text { professional titles }\end{array}$ & 3.87 & 0.895 & 4 & 3.42 & 1.189 & 4 \\
\hline 3 & \multicolumn{7}{|l|}{ Explanation of finance } \\
\hline 3.1 & Explanation of tuition fee & 3.89 & 0.909 & 4 & 3.50 & 1.233 & 4 \\
\hline 3.2 & $\begin{array}{l}\text { Explanation of fees for higher education services according to the regular } \\
\text { education method }\end{array}$ & 3.72 & 0.929 & 4 & 3.37 & 1.217 & 3 \\
\hline 3.3 & $\begin{array}{l}\text { Explanation of the use of state budget resources for irregular tasks or the } \\
\text { order for training, science and technology, }\end{array}$ & 3.70 & 1.048 & 4 & 3.41 & 1.297 & 4 \\
\hline 3.4 & Explanation of the use of aid funds, grants, donations. & 3.80 & 1.085 & 4 & 3.45 & 1.459 & 4 \\
\hline 3.5 & Explanation of the university's spending activities & 3.80 & 0.945 & 4 & 3.09 & 1.506 & 3 \\
\hline 3.6 & $\begin{array}{l}\text { Explanation for setting up university funds (career development fund, } \\
\text { reward fund; welfare fund; student support fund, etc.) }\end{array}$ & 3.54 & 0.938 & 4 & 3.15 & 1.271 & 3 \\
\hline
\end{tabular}


Table 7. Results about the awareness of the survey objects on the method of implementing accountability of universities

\begin{tabular}{|c|c|c|c|c|c|c|c|}
\hline \multirow{2}{*}{ Order } & \multirow{2}{*}{ Content } & \multicolumn{3}{|c|}{ Managers (559) } & \multicolumn{3}{|c|}{ Lecturers (448) } \\
\hline & & $\bar{X}$ & Standard deviation & Level & $\bar{X}$ & Standard deviation & Level \\
\hline 1 & $\begin{array}{l}\text { Declaring the university's mission, vision } \\
\text { and strategic plan ; }\end{array}$ & 3.42 & 1.090 & 4 & 3.25 & 1.168 & 4 \\
\hline 2 & $\begin{array}{l}\text { Setting up and using a set of indicators to } \\
\text { assess the university's activities; }\end{array}$ & 3.36 & 1.095 & 3 & 3.26 & 1.034 & 3 \\
\hline 3 & Implementing "three public"; & 3.66 & 0.833 & 4 & 3.19 & 1.197 & 3 \\
\hline 4 & $\begin{array}{l}\text { Reporting annually / periodically about } \\
\text { university performance results; }\end{array}$ & 3.09 & 1.003 & 3 & 3.02 & 1.202 & 3 \\
\hline 5 & $\begin{array}{l}\text { Implementing mechanisms to ensure } \\
\text { transparency of accountability ; }\end{array}$ & 3.39 & 0.938 & 3 & 3.10 & 1.132 & 3 \\
\hline 6 & $\begin{array}{l}\text { Publicizing the results of the educational } \\
\text { quality verification on the university } \\
\text { website. }\end{array}$ & 3.49 & 1.005 & 4 & 3.21 & 1.216 & 3 \\
\hline & General average & 3.41 & & & 3.17 & & \\
\hline
\end{tabular}

\subsubsection{The Reality of Survey Objects' Awareness on the Method of Implementing Accountability of Universities}

From the results of Table 7 , the following comments can be drawn:

Firstly, the average score of managers' awareness about the method of implementing the university's accountability is 3.40. With this result, managers' awareness of the method of implementing the university's accountability is placed below the Quite appropriate level.

Secondly, the average score of the lecturers' awareness about the method of implementing the accountability of the university is 3.17. With this result, the lecturers' awareness about the method of implementing the university's accountability lies at a Relatively appropriate level.

Thirdly, comparing results about the awareness of managers and lecturers on the method of implementing the university's accountability can be seen, the awareness of managers is higher than that of lecturers.

The results (Table 7) reflect the current situation of managers and lecturers on the implementation of the university's accountability.

\subsubsection{The Reality of Survey Objects' Awareness on Accountability of Universities (According to the University Unit)}

Table 8. Results about the awareness of the survey objects on university accountability (according to the university unit)

\begin{tabular}{|c|c|c|c|c|c|c|c|c|c|}
\hline \multirow{2}{*}{ Universities } & \multirow{2}{*}{ Amount } & \multirow{2}{*}{ Ratio } & \multirow{2}{*}{ Average } & \multirow{2}{*}{$\mathbf{P}$} & \multirow{2}{*}{$\begin{array}{c}\text { Standard } \\
\text { deviation (SD) }\end{array}$} & \multicolumn{2}{|c|}{$95 \%$ confidence interval } & \multirow{2}{*}{ Min } & \multirow{2}{*}{ Max } \\
\hline & & & & & & Upper bound & Lower bound & & \\
\hline Can Tho University & 236 & 23.4 & 3.4728 & \multirow{5}{*}{0.438} & 0.81198 & 3.3686 & 3.5769 & 1.54 & 4.94 \\
\hline Hanoi University of Industry & 288 & 28.6 & 3.4144 & & 0.93320 & 3.3062 & 3.5226 & 1.59 & 5.00 \\
\hline Saigon University & 74 & 7.3 & 3.2604 & & 0.92860 & 3.0453 & 3.4756 & 1.59 & 4.91 \\
\hline $\begin{array}{l}\text { Ho Chi Minh University of } \\
\text { Technical Education }\end{array}$ & 209 & 20.8 & 3.4567 & & 0.89928 & 3.3341 & 3.5794 & 1.44 & 5.00 \\
\hline Vinh University & 200 & 19.9 & 3.3912 & & 0.89849 & 3.2659 & 3.5165 & 1.59 & 5.00 \\
\hline Total/ General Average & 1007 & 100.0 & 3.4209 & & 0.89158 & 3.3658 & 3.4761 & 1.44 & 5.00 \\
\hline
\end{tabular}

From the results of Table 8, we can illustrate the following chart:

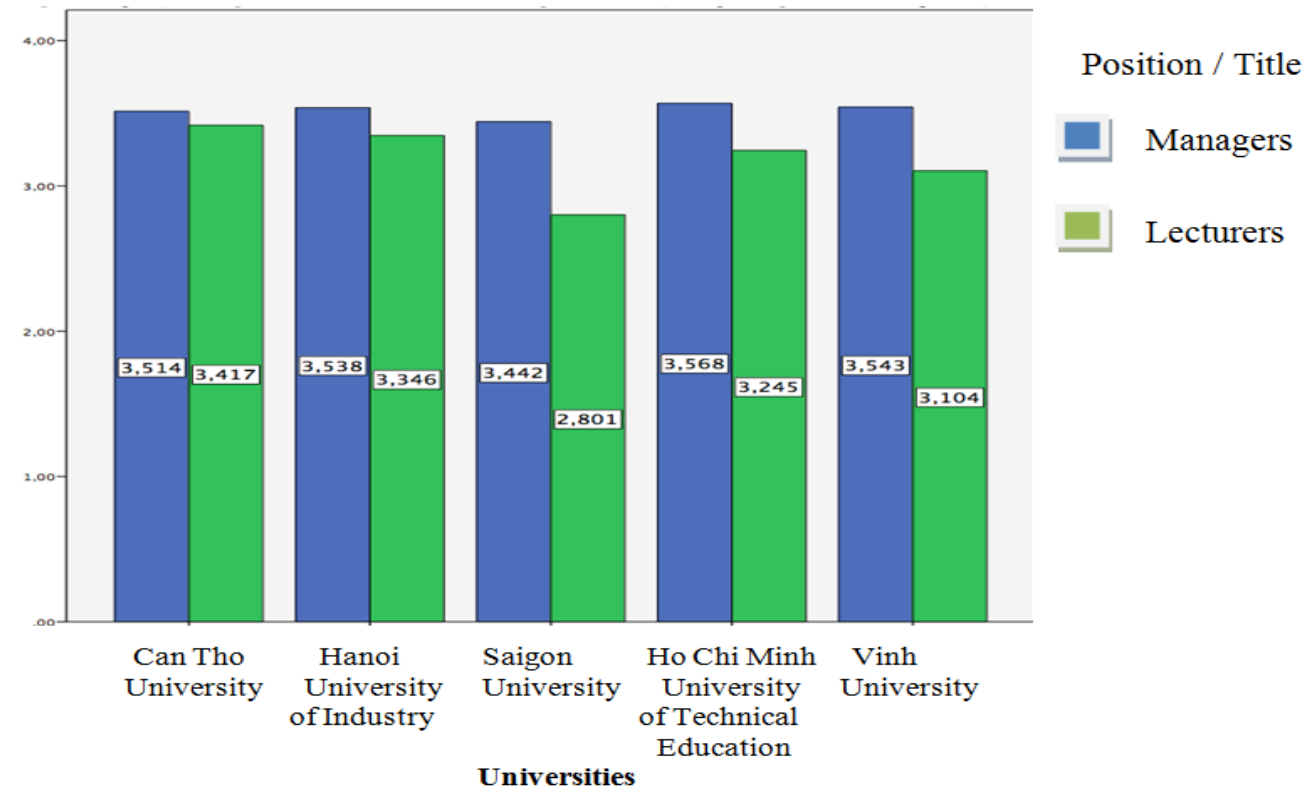

Chart 1. Comparison about results about the awareness of survey objects on the implementation of university accountability (according to the university unit) 
Through the data of Table 8 and chart 1 , it can be drawn the following remarks:

Firstly, awareness of the survey objects (according to the university unit) on the implementation of university the accountability is basically equal. The average score of the universities is 3,4209. With this average score, the awareness of the managers and lecturers of the surveyed universities lies at Relatively appropriate level (level 3).

Can Tho University has the highest average score of awareness; while Saigon University has the lowest average score. The reason why Can Tho University has the highest average score of awareness is that in recent years, the University has implemented many activities related to university autonomy and accountability. Meanwhile, Saigon University is just starting to care about this issue.

Secondly, among universities, the awareness of managers on accountability is always higher than lecturers.

The explanation for this difference is that managers are more likely to learn and participate in the implementation of the accountability than lecturers. From that, their awareness of the implementation of accountability is also more complete and appropriate than that of lecturers.

\section{Awareness Raising Measures for Managers and Lecturers of Public Universities on the Accountability}

\subsection{Organizing Research, Thoroughly Grasping in Universities' Managers and Lecturers about the Need to Implement the Accountability}

One of the reasons why the implementation of university accountability is limited is that managers and lecturers are not properly aware of the need to implement the accountability. Therefore, it is necessary to organize exchanges and discussions among managers and lecturers to agree on the following issues: 1) Accountability is the social responsibility of the university; 2) Implementing the accountability is the obligation of every university manager and lecturer; 3) Each university manager and lecturer participates in implementing the accountability of the assigned tasks.

\subsection{Diversifying the Forms of Dissemination and Propagating so that Managers and Lecturers Are Fully Aware of the Implementation of the Accountability}

The forms of dissemination and propagation for managers and lecturers to be fully aware of the implementation of the accountability need to be diversified, such as organizing a signing ceremony to make transparency of the activity between the Principal and units in the university; building online forums, creating conditions for members inside and outside the university to exchange experiences on implementing accountability, etc.

\subsection{Overcoming the Incorrect and Incomplete Perceptions of Implementing Accountability in Universities}

In the Vietnamese public universities, there are still incorrect and incomplete perceptions of implementing accountability (Accountability is the responsibility of the specialized department; only the specialized department can do accountability tasks, etc.). From these inadequate and incomplete perceptions, implementing accountability has not become a common concern for everyone. Therefore, in order to improve the effectiveness of accountability implementation, it is necessary to overcome incorrect and incomplete perceptions of this activity in Vietnamese public universities.

\section{Conclusion}

Researching the current situation about awareness of managers and lecturers of Vietnamese public universities on the implementation of the accountability is an urgent issue. The reality about awareness of managers and lecturers of Vietnamese public universities on the implementation of the accountability is reflected in the reality about awareness of the concept of accountability; accountability of the university; significance of the importance of implementing accountability; content of implementing accountability and method of implementing accountability. The survey results show that the awareness of managers and lecturers of public universities in Vietnam on implementation of accountability is not high. Therefore, it is necessary to take measures to raise awareness of Vietnamese university managers and lecturers about accountability.

\section{References}

[1] Dang Quoc Bao and Nguyen Thi Hue (2017), Five Articles discussing the implementation of autonomy and accountability of universities, Proceedings "Scientific workshop Autonomy of education and training establishments created in the context of education reform", Vietnam Association of Psycho-Education Sciences, Tay Ninh.

[2] Pham Thi Ly (2012), "University autonomy and accountability: relations among the state, the university and society", Journal of Science and Technology Development. Episode 15 (Q1-2012).

[3] Burke, J (2005), Achieving Accountability in Higher Education: Academic Balancing, Academic and Market Demands, Chapter 1. Many Faces of Accountability, San Francisco: Jossey-Bass: http://www.rockinst.org/... / 2004-10-perfect_accountability_...

[4] Su Yan Pan (2009). "University Autonomy, the State, and Social Change in China". Hong Kong University Press.

[5] Huismam J. and Currie. J. (2004). "Accountability in Higher Education: Bridge Over Troubled Water?" Higher Education 48: 529-541.

[6] Sami. J (2008). The Growing Accountability Agenda: Progress or Mixed Blessing? Outcomes of Higher Education: Quality, relevance and impact Conference, September 8-10, Paris, France; Sami.J The Challenge of Establishing World-Class Universities. Washington DC: The World Bank.

[7] OECD (2011), Pisa in Focus 2011/9 (October).

[8] Pham Thi Ly (2014), About university charter: There is still an empty area - Accountability (http://www.lypham.net/jo omla / February 5, 2014). 
[9] Fielden, J. (2008), Global trends in university governance, WB, Washington DC.
[10] World Bank (2000). "Higher Education In Developing Countries: Peril and Promise" (Washington DC The World Bank), http://www.tfhe.net.

C The Author(s) 2019. This article is an open access article distributed under the terms and conditions of the Creative Commons Attribution (CC BY) license (http://creativecommons.org/licenses/by/4.0/). 